\title{
Alternative Fastening Mechanism for Shear Connectors with Cold-Formed Steel Shapes Involved in Composite Sections
}

\author{
By Xavier Fernando Hurtado Amézquita* \& \\ Maritzabel Molina Herrera ${ }^{ \pm}$
}

\begin{abstract}
Over the past few decades, the use of steel-concrete composite sections has increased globally, to take advantage of compression strength in concrete and tensile strength in steel, ensuring its connection by employing stress transfer elements denominated shear connectors. The main connection systems, endorsed by the current design codes, are used by applying welding as a fastening mechanism to fix connectors and any alternative system must be validated through an experimental program. However, this thermal procedure produces a concentration of residual stresses during the cooling process and the risk of perforation in Cold-Formed Steel sections (CFS), affecting the behavior efficiency of the composite sections. In this research, self-drilling screws are proposed as an alternative mechanical system for connectors fastening. The system efficiency was initially compared to the powder-actuated nails mechanism, validating their advantages of installation and structural behavior. An experimental program was carried out to validate the capacity and performance of the system, through screw shear tests and full-scale beam tests. Therefore, it was possible to characterize the local behavior in the fastening mechanism and the overall behavior in the composite system. According to results, self-drilling screws are a viable alternative to use as a fastening mechanism in shear connectors for CFS and concrete composite sections. The composite system developed full capacity, even in inelastic range, without disconnection between materials. Self-drilling screws remained fixed on steel shapes without mechanical damage, allowing greater deformations than displacements under service conditions.
\end{abstract}

Keywords: Composite sections, Shear connector, Cold-formed steel, Fastening mechanism, Self-drilling screws

\section{Introduction}

Over the past few decades, the use of steel-concrete composite sections has increased globally. The basic principle of joining these two materials is to take advantage of their mechanical properties. In this way, steel sections can be loaded to high compression force, but efficiency is reduced in slender members due to their potential instability induced by lateral buckling, torsional buckling and/or local buckling, mainly in open sections (Valencia 2010). Therefore, optimization

\footnotetext{
*Assistant Professor, Department of Civil Engineering, La Salle University, Colombia.

${ }^{ \pm}$Associate Professor, National University of Colombia, Colombia.
} 
of the composite section is based on the concrete slab to withstand compression stresses and on the steel shape to withstand tensile stresses.

Assembly of composite sections implies the attachment of stress transfer elements between materials, called shear connectors. These components can control possible uplifts and relative displacements on the connection interface. Moreover, the strain state is also modified due to the inclusion of shear connectors, thus a two-materials system becomes a composite system.

This system was initially proposed for bridges, and due to its good structural performance, its uses were expanded to flooring systems in buildings (Lakkavalli and Liu 2006).

Recently, within technologies with better structural efficiency, Cold-Formed Steel (CFS) sections have increased their structural applications in medium and small buildings (Hossain 2005), becoming a competitive alternative concerning Hot-Rolled Steel (HRS) sections, which are heavier but commonly used in conventional infrastructure (Hancock 2003).

The main advantages of CFS are versatility in the generation of different cross-sections, the possibility of using it in long spans, ease in industrial production, high strength-to-weight ratio and speed in packaging, transport and assembly (Yu and LaBooube 2010). Moreover, these sections are considered as an alternative to build sustainable structures in "green" construction (Alhajri et al. 2016, Irwan and Hanizah 2009, Lawan et al. 2015).

Currently, design codes, such as AISC 360, AISI S-100, NBR8800, AS/NZ 4600, S136, Eurocode4, JSCE/09, involve welding as a conventional methodology to fix studs, channels or perfobond ribs as the regulated shear connectors (AISI 2016, AISC 2016, ABNT 2008, AS/NZ 2005, CSA 2007, ECS 2004, JSCE 2009). This thermal process generates uncertainty in the structural behavior of the composite systems because it induces local residual stresses in steel sections and connectors, reducing both its mechanical capacity and efficiency. Moreover, in CFS, electrodes can perforate steel shape plates (Figure 1), due to the high temperature and limited thickness of the steel section (Erazo and Molina 2017).

Figure 1. Damages in CFS Steel Plates Caused by Welding Process

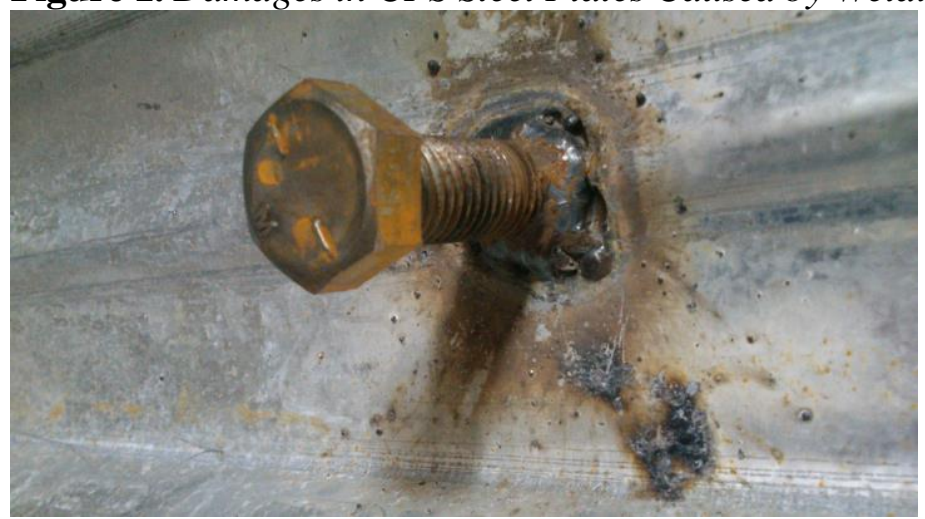

Source: Erazo and Molina 2017. 
Therefore, knowing the disadvantages of welding, it is convenient to develop design methodologies, incorporating efficient alternative mechanisms for the mechanical fastening of shear connectors (Merryfield et al. 2016).

In this research, self-drilling screws are validated as an alternative mechanical system to fasten connectors. An experimental program was carried out in order to quantify the failure capacity of the system, involving screw shear tests and fullscale beam tests. The advantages of the proposed system were confirmed according to the mechanical adhesion and structural behavior showed.

\section{Background}

Different alternative mechanical fastening systems in CFS sections have been studied, to ensure an adequate system connection, regardless of the welding process.

Hanaor (2000) evaluated a bolts and nuts system and expansion anchor bolts in hardened concrete as shear connectors, through experimental push-out tests and full-scale beam tests. Displacements and rotations were observed in the bolts due to adjustments and clearance of the bolt predrilled holes, inducing early sliding between materials. Moreover, bolts presented ductile behavior, allowing large deflections in the composite systems.

Using bolted screws as transfer elements, Queiroz et al. (2010) evidenced local deformations in CFS sections, induced by stress concentration due to the limited thickness, reducing the capacity in the composite systems.

Figure 2. Local Buckling in CFS-Concrete Composite Sections a) Push-Out Test b) Full Scale Beam Test

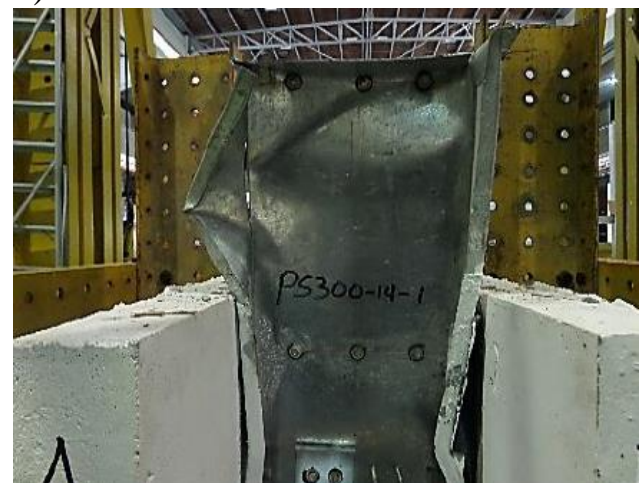

a)

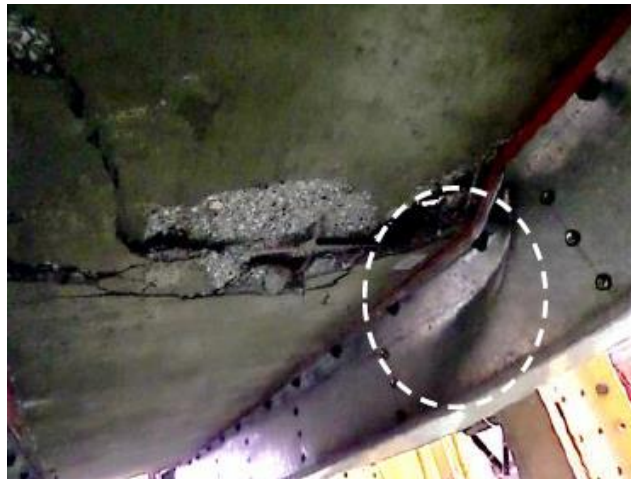

b)

Source: Lawan et al. 2015.

Complete studies of bolted shear connectors were developed by Lawan et al. (2015), Lawan and Tahir (2015) and Tahir et al. (2016a, b), which involved the effects of bolt size and spacing between connectors in the behavior of CFSconcrete composite systems. Experimental programs included full-scale bending tests and push-out tests. According to the whole push-out results, the greater diameter size the better performance in the composite system is, but the failure 
mode depends on this factor. Therefore, M12 bolts showed shear in screws, and greater sizes presented longitudinal and transversal cracks in concrete, although some specimens were not fully characterized due to the local buckling in the steel shape (Figure 2a). Bending tests also showed ductile behavior, as well as in the results of Hanaor (2000), allowing displacements up to service limit conditions. The main failure mode was transverse cracks beneath the concrete slab at load application points, accompanied by local buckling in steel shape (Figure 2b). In this way, the thickness plate becomes a relevant factor in the behavior of CFSconcrete composite systems.

Fontana and Bartschi (2002) applied powder-actuated fastening systems to fix alternative rib shear connectors made by cutting and folding CFS plates. Although the system was efficient, failure was generated mainly by connector bearing in push-out tests, due to the thickness plate, disassembling the composite systems.

Derlatka et al. (2019) also studied the effectiveness of powder-actuated nails in top-hat shear connectors, initially proposed by Lawson et al. (2001). In general, push-out test results showed ductile behavior in the composite system, being more effective in the shortest connectors $(60 \mathrm{~mm})$. Most of the failure modes were associated with rotation and cutting in steel nails, and tearing in shear connectors, with previous excessive deformations, decoupling the composite system, without evidence of damages in the concrete slabs (Figure 3). Currently, this mechanism is applied in commercial systems such as HILTI $^{\circledR}$ and TECNARIA ${ }^{\circledR}$. These companies specify those systems must be used on plates of more than $6 \mathrm{~mm}$ thickness to avoid perforations, due to the force on fired nails. However, those products require a special tool to make this installation an efficient procedure.

Figure 3. Typical Failure Modes in Powder-Actuated Fastening Systems a) Tearing in Rib Shear Connector b) Rotations and Decoupling of Composite System in Push-Out Test

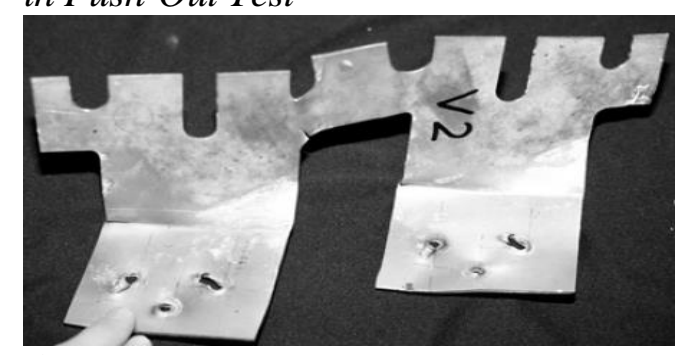

a)

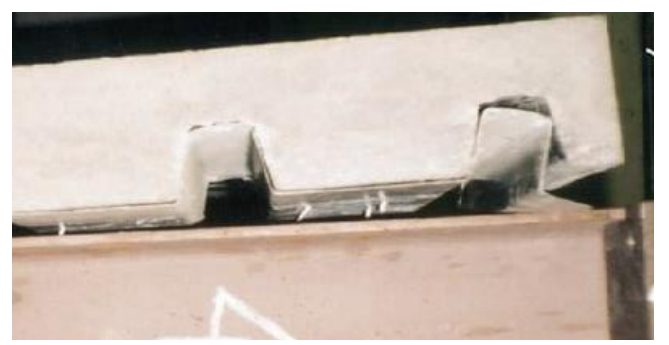

b)

Source: Fontana and Bärtschi 2002, Derlatka et al. 2019.

Lakkavalli and Liu (2006), Merryfield et al. (2016) and Kyvelou et al. (2017, 2018) used self-drilling screws as shear connectors in full-scale bending tests for CFS composite beams. Study factors involved in the researches were connectors spacing and comparison to other types of transfer elements such as bent-up tabs, bolt connectors and puddle welding. They found that the better system performance the shorter spacing is, developing higher bearing loads. The behavior was

${ }^{1}$ https://www.hilti.com.co, https://www.tecnaria.com. 
characterized by high inelastic deformations, inducing bending and shear in screws, sliding of concrete slab on the steel beam and local buckling in steel shape (Figure 4). Self-drilling screws presented limited capacity, compared to welded systems; thus, it was necessary to install many connectors, becoming a nonpractical and expensive system.

Figure 4. Failure Modes in Self-Drilling Shear Connectors a) Bending in Screws b) Shear in Screws c) Local Buckling in Steel Shape

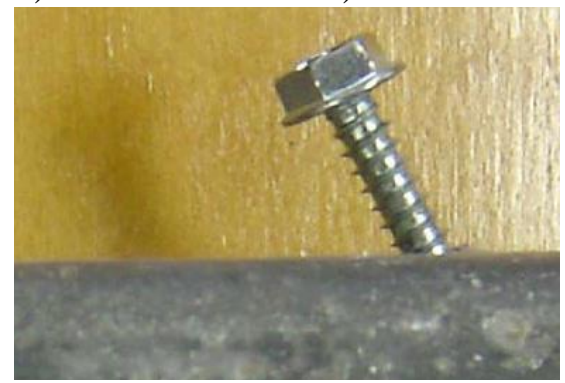

a)

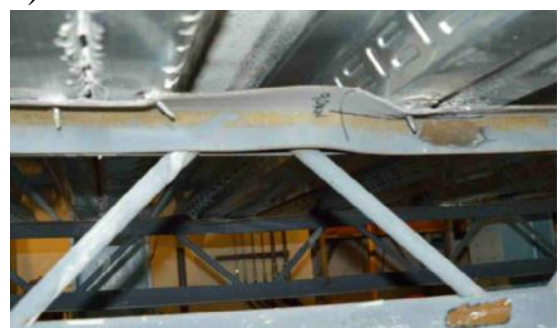

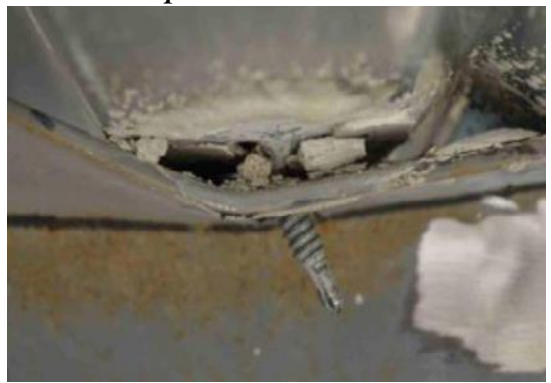

b)

c)

Source: Lakkavalli et al. 2006, Merryfield et al. 2016.

All these types of shear connectors presented an adequate connection and stress transfer between materials. In contrast, bolted joints have not been technically endorsed yet, due to the lack of standardization of tests and results.

\section{Methodology}

\section{Materials}

Experimental tests involved two types of concrete compressive strength to build $100 \mathrm{~mm}$ thickness slabs: $21 \mathrm{MPa}$ and $28 \mathrm{MPa}$.

The mechanical characteristics of steel differed according to each type of element used:

- Shear connectors: ASTM A424 - Type II, in 1.9 mm thickness.

- Screw shear test samples: ASTM A424 - Type II, in $1.5 \mathrm{~mm}$ and $2.0 \mathrm{~mm}$ thicknesses.

- Steel beams (C220x80x2.5): ASTM A1011, in 2 m and 4 m length, and $2.5 \mathrm{~mm}$ thickness.

- Self-drilling screws: ASTM A449 - Type I, in 6 mm diameter. 
- Fired nails: HRC 57.5 (ASTM A276 440C), in 3 mm diameter.

Table 1 summarizes the main nominal mechanical properties of the materials.

Table 1. Nominal Properties of the Materials

\begin{tabular}{|l|c|c|c|c|c|}
\hline \multirow{2}{*}{$\begin{array}{l}\text { Structural } \\
\text { Component }\end{array}$} & \multicolumn{2}{|c|}{ Concrete } & \multicolumn{3}{c|}{ Steel } \\
\cline { 2 - 6 } & Strength (f'c) & $\begin{array}{c}\text { Modulus } \\
\text { of Elasticity } \\
\text { (Ec) }\end{array}$ & $\begin{array}{c}\text { Yield } \\
\text { Strength } \\
\text { (fy) }\end{array}$ & $\begin{array}{c}\text { Ultimate } \\
\text { Tensile } \\
\text { Strength } \\
\text { (fu) }\end{array}$ & $\begin{array}{c}\text { Modulus } \\
\text { of Elasticity } \\
\text { (Es) }\end{array}$ \\
\cline { 2 - 6 } & $(\mathrm{MPa})$ & $(\mathrm{MPa})$ & $(\mathrm{MPa})$ & $(\mathrm{MPa})$ & $(\mathrm{MPa})$ \\
\hline $\begin{array}{l}\text { Concrete } \\
\text { Slab }\end{array}$ & 21 & 21,736 & & & \\
\hline Steel Beam & 28 & 25,098 & & & \\
\hline $\begin{array}{l}\text { Shear } \\
\text { Connectors }\end{array}$ & & & 340 & 410 & 200,000 \\
\hline $\begin{array}{l}\text { Self-Drilling } \\
\text { Screws }\end{array}$ & & & 240 & 345 & 200,000 \\
\hline Fired nails & & & 448 & 840 & 200,000 \\
\hline
\end{tabular}

Source: Authors.

\section{Experimental Program}

Three experimental tests were programmed to characterize the alternative fastening mechanism: Fastening system comparison, screw shear test and fullscale beam test. All of them allowed identifying and qualifying the behavior of the system under service conditions, both qualitatively and quantitatively, acting in composite sections.

\section{Fastening System Comparison}

In this research, powder-actuated nails and self-drilling screw systems were selected for preliminary evaluation, which do not require sophisticated and specialized machines, compared to welded systems, increasing ease of installation and reducing operating costs in the construction field.

The efficiency of the systems was evaluated through a fastening experimental test, in two C220x80x2.3 mm back to back shapes (Figure 5a), with steel yield strength (fy) equal to $340 \mathrm{MPa}$. Figure 5 shows the geometrical characteristics of the systems to be compared, as well as the installation procedure required in each case. 
Figure 5. Fastening Mechanisms Compared a) Configuration of Test (Units in $\mathrm{mm})$ b) Installation of Powder-Actuated Nails c) Geometric Detail of Fired Nails d) Installation of Self-Drilling Screws e) Geometric Detail of Self-Drilling Screws Steel shapes $\mathrm{C} 220 \times 80 \times 2.3 \mathrm{~mm}$

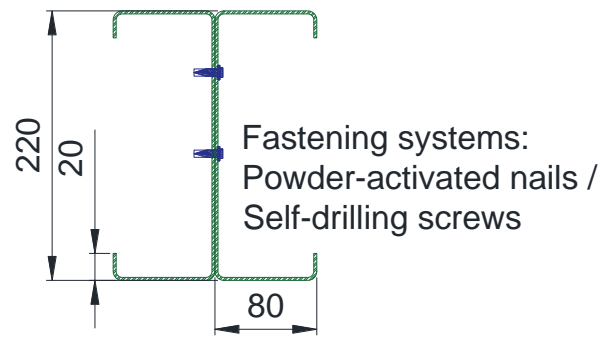

a)

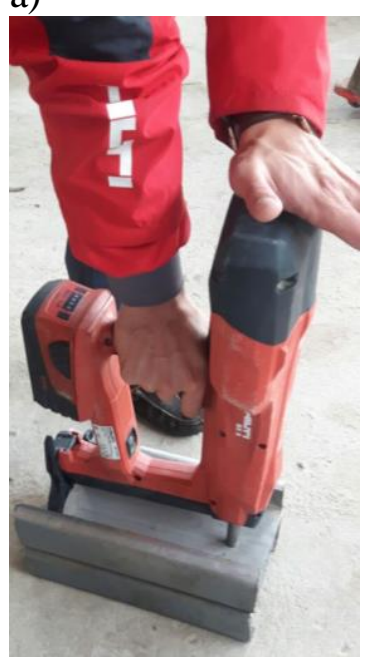

b)

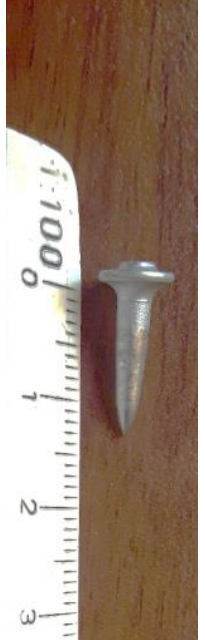

c)

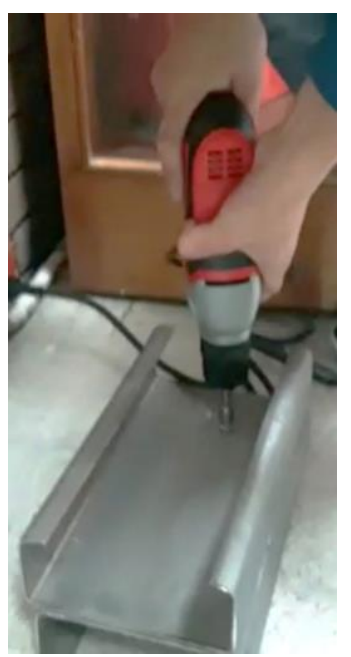

d)

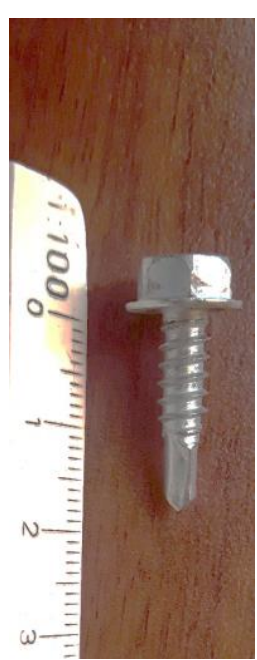

e)

Source: Authors.

Screw Shear Test

The mechanical strength of the connection was evaluated by experimental screw shear tests. The axial tensile load was applied by Universal Testing Machine on steel plate samples, which were connected by self-drilling screws. The configuration of specimens is presented in Figure 6, and all the arrangements are defined in Table 2, where the thickness effect was validated in the failure capacity of the system. The test setup is shown in Figure 7.

Figure 6. Configuration of Test Samples in Screw Shear Test (Units in mm)

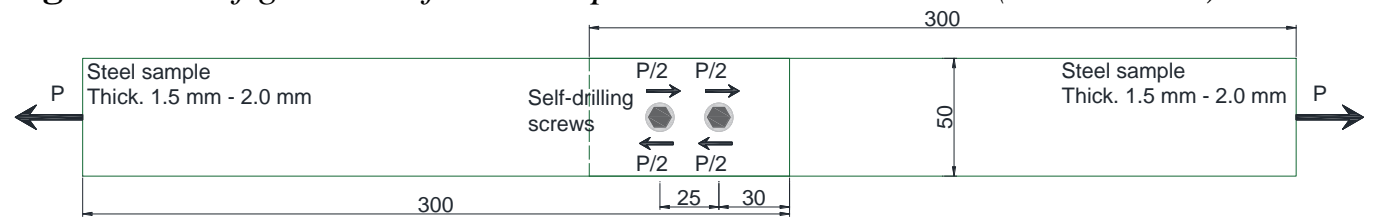

Source: Authors. 
Figure 7. Screw Shear Test Setup a) Front View b) Side View
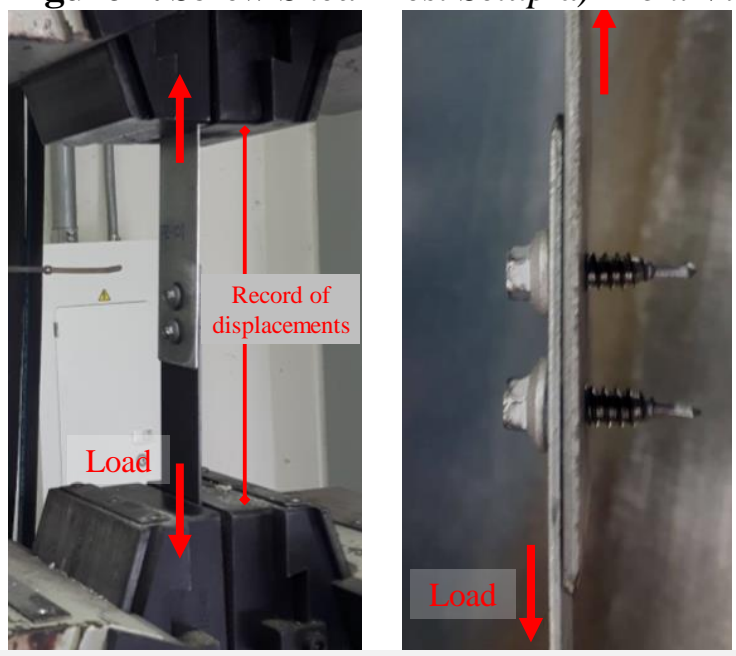

a)

b)

Source: Authors.

According to the AISI S100, bolted connections must be designed for bearing failure in steel plates and shear in screws. Therefore, the ultimate limit states were previously reviewed, obtaining the nominal loads presented in Table 2.

Table 2. Arrangement of Specimens in Screw Shear Test

\begin{tabular}{|c|c|c|c|c|c|c|c|c|}
\hline \multirow{3}{*}{ No. } & \multicolumn{2}{|c|}{ Upper plate } & \multicolumn{2}{|c|}{ Lower plate } & \multicolumn{2}{|c|}{ Screws } & \multicolumn{2}{|c|}{ Nominal resistance } \\
\hline & 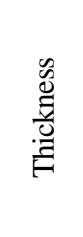 & 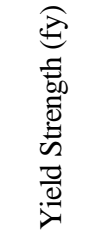 & 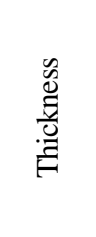 & 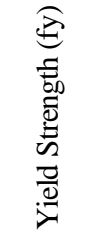 & 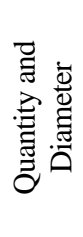 & 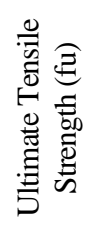 & 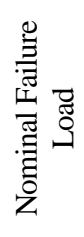 & $\begin{array}{c}\text { Type of } \\
\text { nominal failure }\end{array}$ \\
\hline & $(\mathrm{mm})$ & (MPa) & $(\mathrm{mm})$ & (MPa) & $(\mathrm{mm})$ & (MPa) & $(\mathrm{kN})$ & \\
\hline PR-01 & 1.5 & 240 & 2.0 & 240 & $2 \times 6$ & 324 & 13.04 & Plate bearing \\
\hline $\begin{array}{c}\text { PR- } \\
02 / 04\end{array}$ & 1.5 & 240 & 1.5 & 240 & $2 \times 6$ & 324 & 13.04 & Plate bearing \\
\hline $\begin{array}{c}\text { PR- } \\
03 / 05\end{array}$ & 2.0 & 240 & 2.0 & 240 & $2 \times 6$ & 324 & 18.32 & Shear screws \\
\hline
\end{tabular}

Source: Authors

Because metal drilling and molding work induce stress concentrations and temperature rise, a thermal scan was performed during the manufacturing process of the test specimens, using a FLIR E40 thermal imaging camera. It was found that the final temperature is not as relevant as in the welding processes, remaining below $38{ }^{\circ} \mathrm{C}$ due to the manual handling of parts. Figure 8 shows the thermal image taken from the scanner test. 
Figure 8. Installation Process of Self-Drilling Screws. Comparison between Real View and Thermal Image, Using a FLIR E4O Thermal Imaging Camera
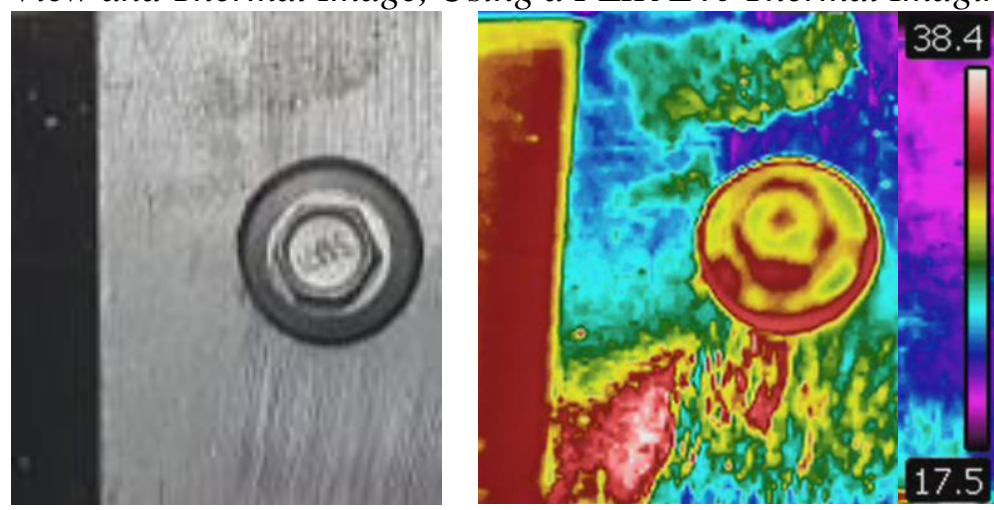

Source: Authors.

\section{Full-Scale Beam Test}

Bending tests on composite beams allow characterizing the global behavior of the fastening system during the service conditions, acting as a link between shear connectors and the steel section. In this research, 4-point-load experimental bending tests were carried out on simply supported specimens, assembled by a double C220x80x2.5 mm box section with a concrete slab (Figure 9a). Moreover, the ends of the steel beam were filled with concrete, to prevent local buckling, due to reaction forces. The setup of experimental tests is presented in Figure 9.

Figure 9. Setup of Full-Scale Beam Tests a) Cross Section b) Four-Point Bending Test Setup c) General Arrangement of Shear Connectors. Top View (Units in mm)

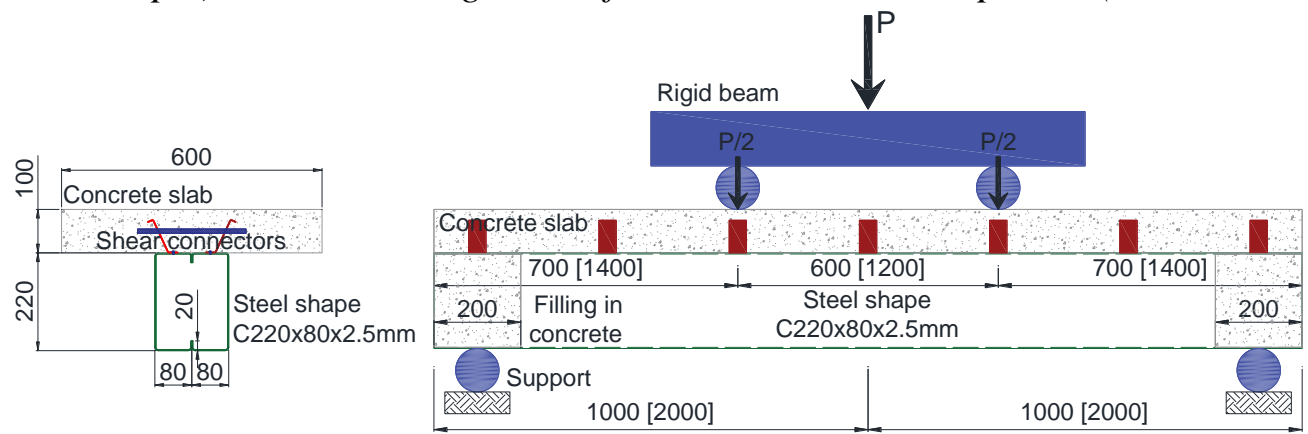

a)

b)

$\begin{gathered}\text { Self-drilling } 20 \\ \text { screws } 0.0\end{gathered}$
Steel section

c)

Source: Authors.

The load was applied through a hydraulic jack, with a capacity of $500 \mathrm{kN}$, and transmitted through rails to two-point loads on the concrete slab. The displacement control was employed for the monotonic test (Figure 10). 
Figure 10. Full-Scale Beam Test Setup

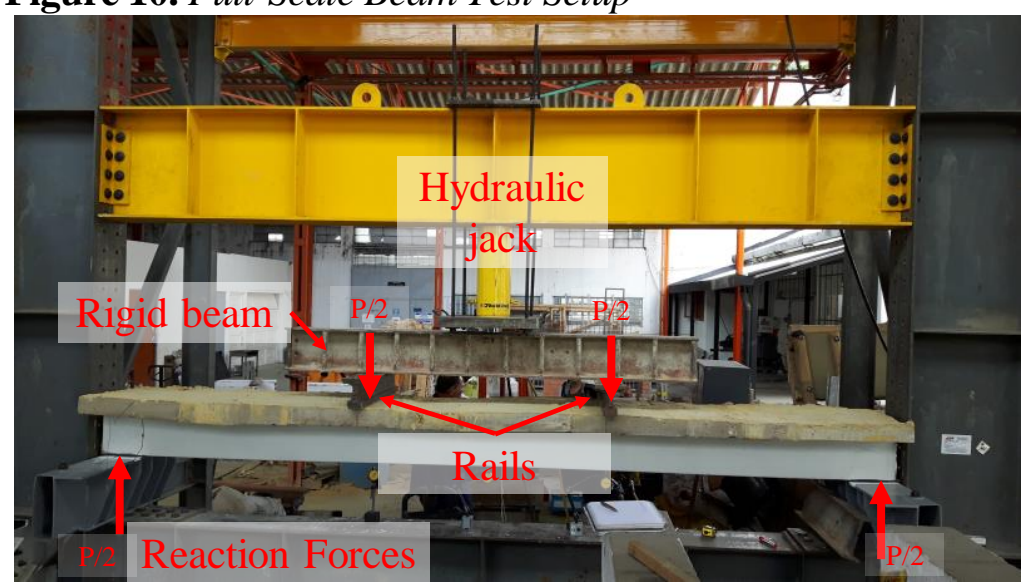

Source: Authors.

Beams deflections were recorded using dial indicators, located at thirds of the length, to verify symmetry in behavior. Additionally, strain gauges were attached to the steel sidewall to evaluate strain status throughout the tests (Figure 11).

The deformation states and the final deflection of the system were evaluated, as well as the maximum failure loads and failure modes. The configuration of specimens is defined in Table 3.

Figure 11. Experimental Test Instrumentation

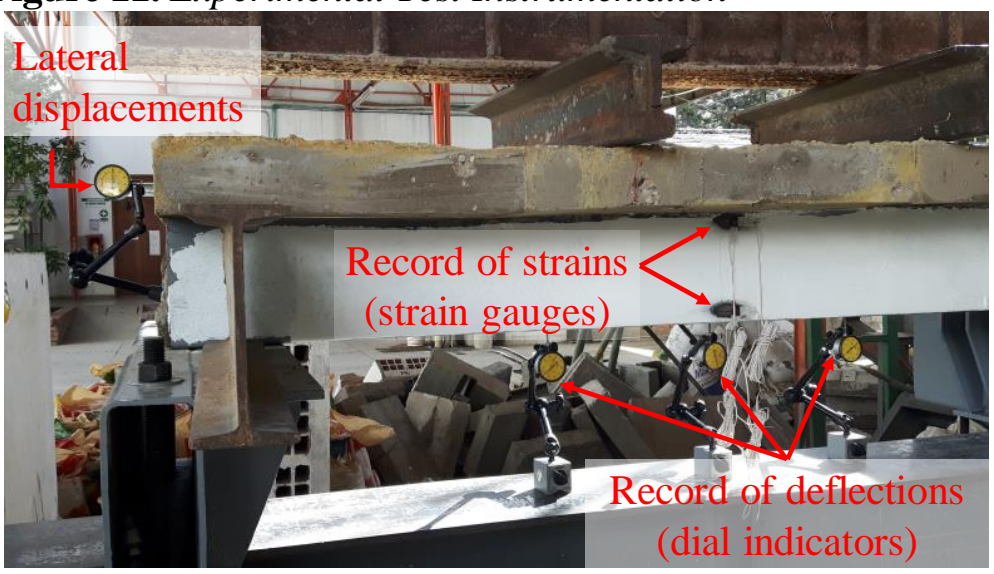

Source: Authors. 
Table 3. Configuration of Specimens in Full-Scale Beam Test

\begin{tabular}{|c|c|c|c|c|c|c|c|}
\hline \multirow{3}{*}{ No } & \multicolumn{2}{|c|}{ Concrete Slab } & \multicolumn{3}{|c|}{ Steel Section } & \multicolumn{2}{|c|}{ Shear Connectors } \\
\hline & 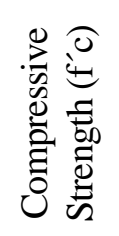 & 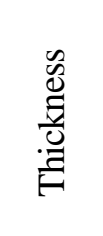 & 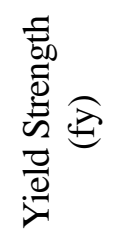 & 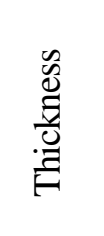 & $\begin{array}{l}\bar{E} \\
\overline{00} \\
\bar{\Xi} \\
\end{array}$ & 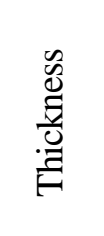 & 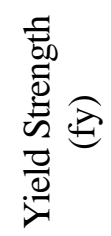 \\
\hline & (MPa) & $(\mathrm{mm})$ & $(\mathrm{MPa})$ & $(\mathrm{mm})$ & (m) & $(\mathrm{mm})$ & (MPa) \\
\hline $21-2$ & 21.0 & 100 & 340 & 2.5 & 2.0 & 1.9 & 240 \\
\hline $21-4$ & 21.0 & 100 & 340 & 2.5 & 4.0 & 1.9 & 240 \\
\hline $28-2$ & 28.0 & 100 & 340 & 2.5 & 2.0 & 1.9 & 240 \\
\hline $28-4$ & 28.0 & 100 & 340 & 2.5 & 4.0 & 1.9 & 240 \\
\hline
\end{tabular}

Source: Authors.

An analytical study was conducted, which allowed predicting the nominal failure loads.

According to AISC-10 and Eurocode4 recommendations, this type of noncompact steel shapes should be analyzed under elastic methods, due to its susceptibility to local buckling in steel plates because of the limited thickness. This condition avoids developing the plastic capacity on the entire steel section before the failure of the composite system. Table 4 shows the analysis of nominal loads, applying Strain Compatibility Method (SCM), by transforming a concrete crosssection into an equivalent steel section, to study only one material.

Although the plastic capacity of the steel cannot be developed, Table 4 also includes plastic analysis applying the Plastic Stress Distribution Method (PSDM), in order to know a possible range of workloads before failure.

The full composite action is considered in both analyses. Figure 12a includes stresses distribution in SCM and Figure 12b PDSM analyses.

Figure 12. Stress State in Composite Sections a) Elastic Analysis b) Plastic Analysis (Units in mm)

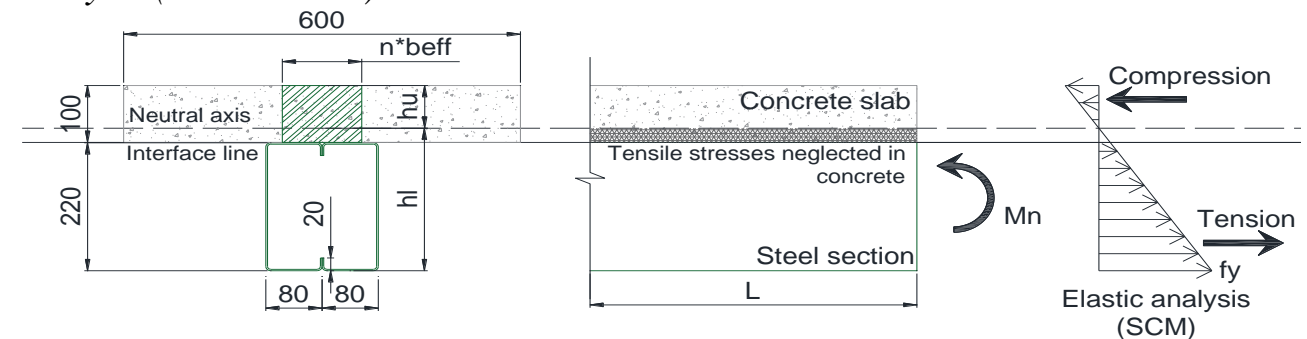

a)

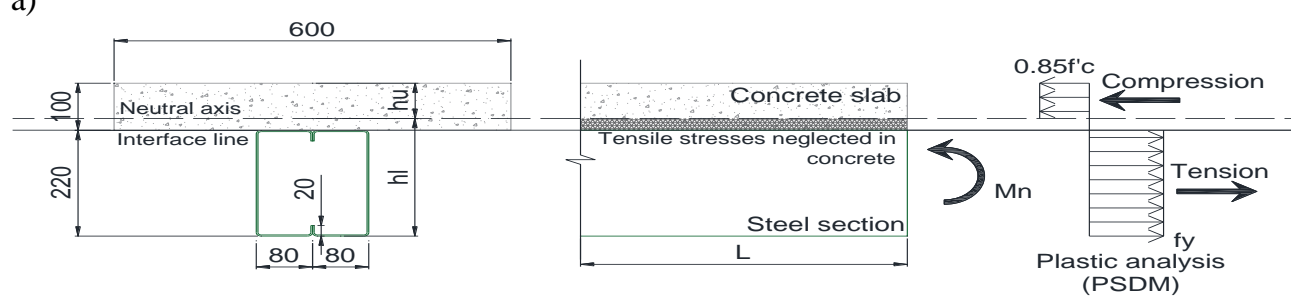

b)

Source: Authors. 
Table 4. Nominal Loads in Composite Sections

\begin{tabular}{|l|l|c|c|c|c|}
\hline \multicolumn{2}{|l|}{$\begin{array}{l}\text { Characteristics of the } \\
\text { composite systems }\end{array}$} & \multicolumn{2}{|c|}{$\begin{array}{c}\text { Elastic analysis } \\
\text { Strain-Compatibility } \\
\text { Method (SCM) }\end{array}$} & \multicolumn{2}{|c|}{$\begin{array}{c}\text { Plastic analysis } \\
\text { Plic Stress Distribution } \\
\text { Method (PSDM) }\end{array}$} \\
\hline Modular ratio & $\mathrm{n}$ & 0.109 & 0.125 & --- & -- \\
\hline $\begin{array}{l}\text { Upper distance } \\
\text { neutral axis }\end{array}$ & $\mathrm{hu}(\mathrm{mm})$ & 87.50 & 83.53 & 63.37 & 47.53 \\
\hline $\begin{array}{l}\text { Lower distance } \\
\text { neutral axis }\end{array}$ & $\mathrm{hl}(\mathrm{mm})$ & 232.50 & 236.47 & 256.63 & 272.47 \\
\hline $\begin{array}{l}\text { Nominal resistant } \\
\text { moment }\end{array}$ & $\begin{array}{l}\mathrm{Mn} \\
(\mathrm{kN} * \mathrm{~m})\end{array}$ & 65.19 & 67.12 & 121.03 & 126.41 \\
\hline $\begin{array}{l}\text { Nominal resistant } \\
\text { Load 2 m }\end{array}$ & $\mathrm{Pn}(\mathrm{kN})$ & 186.25 & 191.78 & 345.8 & 361.16 \\
\hline $\begin{array}{l}\text { Nominal resistant } \\
\text { Load 4 m }\end{array}$ & $\mathrm{Pn}(\mathrm{kN})$ & 93.12 & 95.89 & 172.9 & 180.58 \\
\hline
\end{tabular}

Source: Authors.

\section{Results and Discussion}

\section{Fastening System Comparison}

According to experimental results, both the powder-actuated nails and the self-drilling screws systems perforated the plates and connected the steel shapes. The final state of the fastening elements is shown in Figures 13 and 14.

Figure 13. Fastening Systems Installed on Test Specimens (Top View)

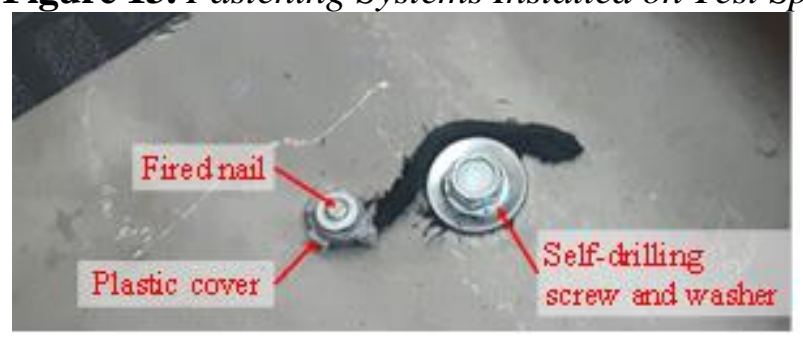

Source: Authors.

During the installation process, two relevant disadvantages were evidenced in powder-actuated nails systems:

- The fired nails had plastic covers, which remained after installation. This cover is necessary to direct the shots but restricts the useful length during the service conditions.

- Friction and adhesion with the steel shape were not enough due to the flat shank geometry of the fired nails. Therefore, the link between elements is lost quickly, even under low external loads. 
Physical differences between the final state of fastening systems are evidenced in Figure 14. Thus, the limited capacity of the nail lengths becomes relevant.

Figure 14. Fastening Systems Installed on Test Specimens a) Bottom View b) Front View

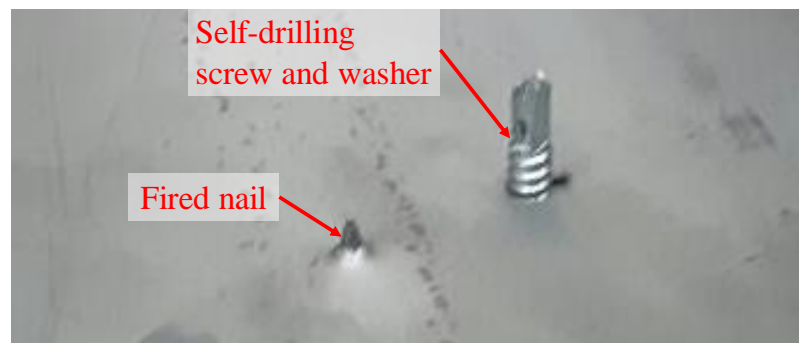

a)

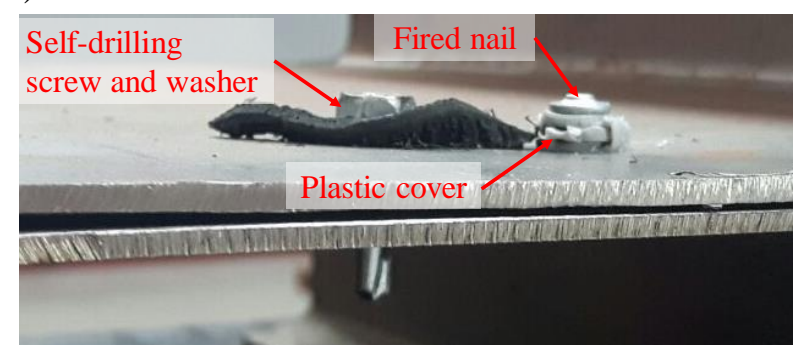

b)

Source: Authors.

In contrast, the self-drilling screws system was an efficient fixing mechanism, ensuring the integrity of the assembled elements, despite the thickness restriction. Moreover, specialized tools are not required during the installation process, which makes it an easy system to be implemented on the field, without generating additional operating costs and avoiding the impacts presented by welding processes.

Therefore, guaranteeing the advantages of installation, self-drilling screws were used in the other characterization tests.

\section{Screw Shear Test}

Experimental screw shear tests were carried out according to the configuration presented in Table 2. Load and slip data were recorded during the test for all the specimens. Curves are presented in Figure 15, including the ultimate nominal limit states as horizontal lines. 
Figure 15. Load-Slip Curves for Experimental Screw Shear Test

\section{LOAD-SLIP DIAGRAM}

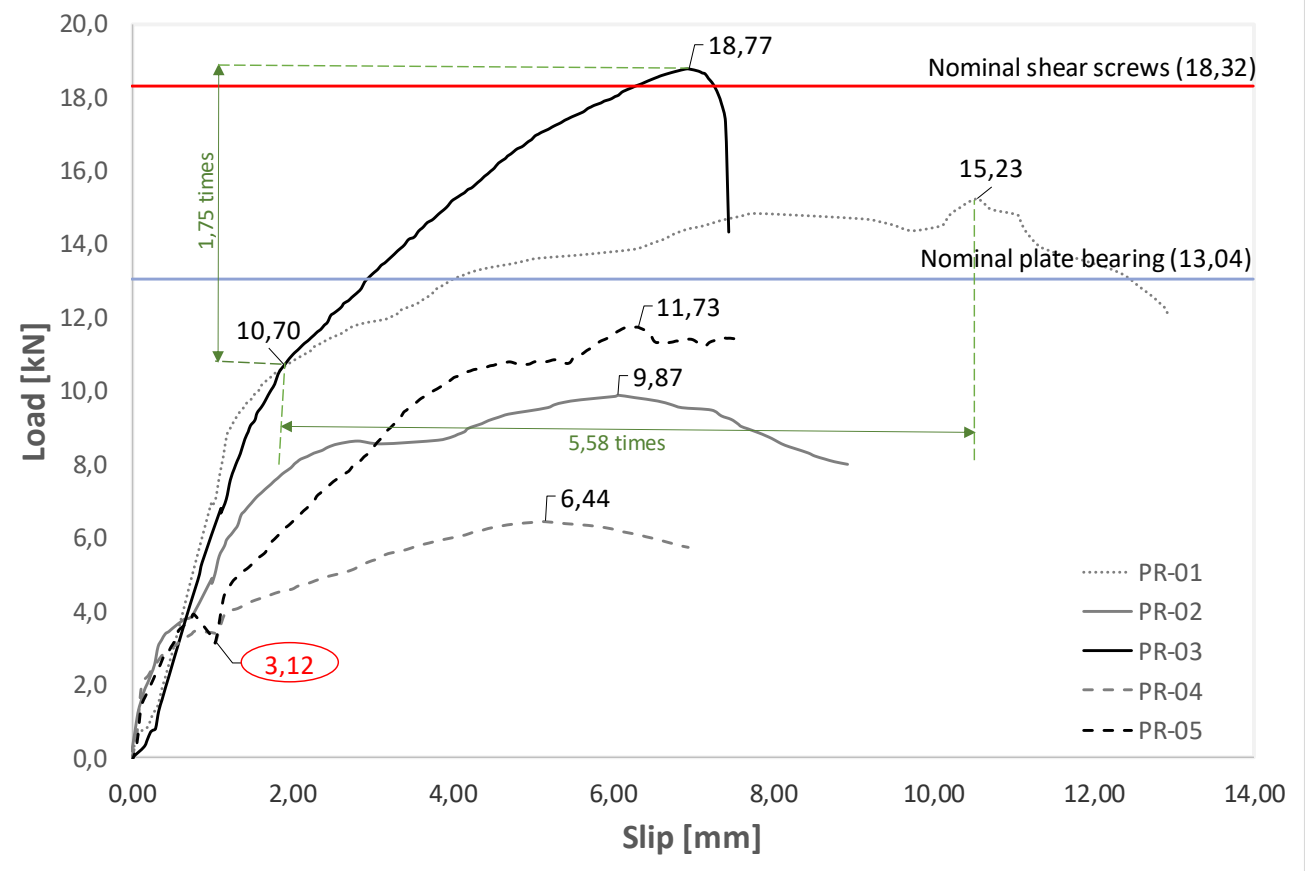

Source: Authors.

According to results, the $2.0 \mathrm{~mm}$-thickness plate specimens, even in samples with combined thickness, exhibited a more stable behavior than $1.5 \mathrm{~mm}$-thickness, reaching ultimate loads greater than nominal values: 1.02 times in PR-03 and 1.17 times in PR-01. Both specimens presented a similar elastic path before the initial damages in plates. Then, depending on the thicknesses, PR-03 showed a maximum failure load of 1.75 times the elastic load and PR-01 developed more inelastic displacements (5.58 times the elastic displacement) due to the deformability of the system.

The PR-02 and PR-04 (1.5 mm-thickness) could not reach the nominal plate bearing, which was obtained according to the AISI S100 formulation (Table 2). Therefore, it is relevant to review the applicability of the design formulation in plate thicknesses of less than $2.0 \mathrm{~mm}$.

Although the PR-05 was $2.0 \mathrm{~mm}$-thickness, it had an early instability due to machine handling, causing deterioration in the system capacity. A similar situation occurred in the PR-04, thus these samples were not taken into account within the representative information.

The failure modes presented in the experimental tests are shown in Figure 16.

Fragile failure was induced by shearing in screws, mainly in specimens PR-03 and PR-05, as shown in Figure 16a. The maximum inelastic displacements were limited to less than $7.5 \mathrm{~mm}$, which additionally induced small tearing around the perforation area.

Screw tilting and plate separation failure were characterized by loss of adhesion in the system, evidenced in PR-02 and PR-04 specimens, as presented in 
Figure 16b. The main resistant force was given by contact locking of screws thread on plates. Total system displacements increased, reaching $9.0 \mathrm{~mm}$.

Specimen PR-01 failed due to tension on the net section in the thinnest plate, through one of the joint perforations and a small tearing in the other (Figure 16c). As in PR-02 and PR-04 specimens, screws were not affected in this system. Final displacements reached $13.0 \mathrm{~mm}$.

Figure 16. Failure Modes Presented in the Screw Shear Test a) Failure due to Screw Shear b) Failure due to Screw Tilting and Plate Separation c) Failure due to Tension on the Net Section in Plate

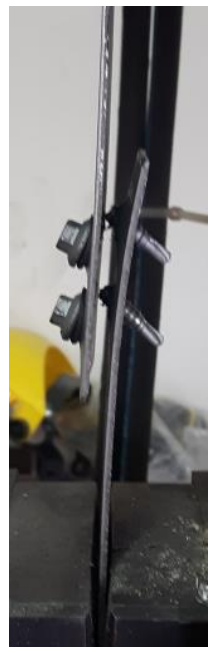

a) Source: Authors.

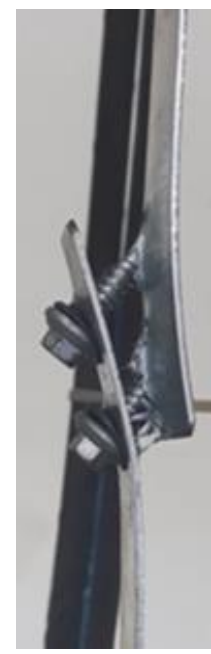

b)

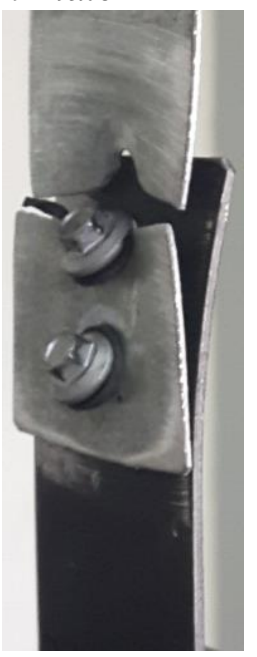

c)

Therefore, it is concluded that the self-drilling fastening system allows guaranteeing elements fixing. On plates with thicknesses greater than $2.0 \mathrm{~mm}$, the predominant failure mode is screws shearing. In plates of smaller thicknesses, the bonding capacity is limited by plate bearing. In configurations with combined thickness, the final resistance is governed by tension on the net section in the thinnest plate.

In terms of maximum displacement, according to results presented in Figure 15 , it can be concluded that the greatest ductility is presented in joints with a thickness of less than $2.0 \mathrm{~mm}$, in both combined thickness systems, or with the same thickness.

\section{Full-Scale Beam Test}

Different arrangements were considered in the experimental bending test, involving the compressive strength of concrete and beam length (Table 3), in order to evaluate the fastening mechanism under real composite systems. The final condition of the specimens is shown in Figure 17, where the baseline is included to contrast the degree of deformation, showing large displacements and exceeding widely the elastic behavior of the systems (more than 2.5 times for $2 \mathrm{~m}$-long beams and more than 1.7 times for 4 m-long beams). 
Figure 17. Final Condition of Specimens in Full-Scale Beam Test a) $2 \mathrm{~m}$-Long Beams b) 4 m-Long Beams

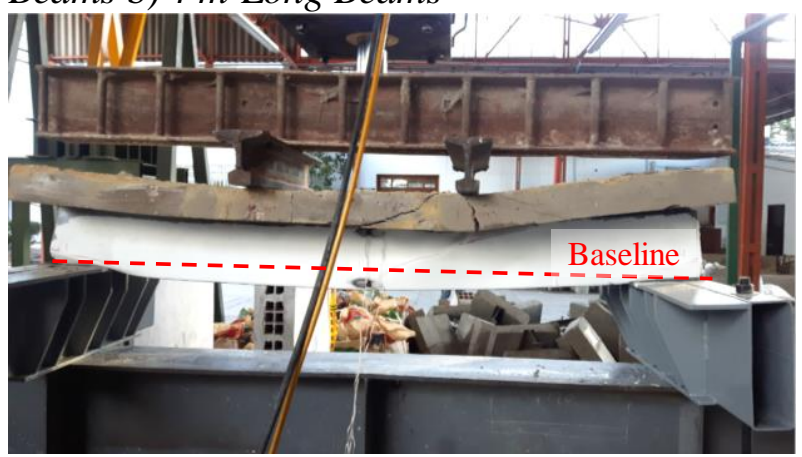

a)

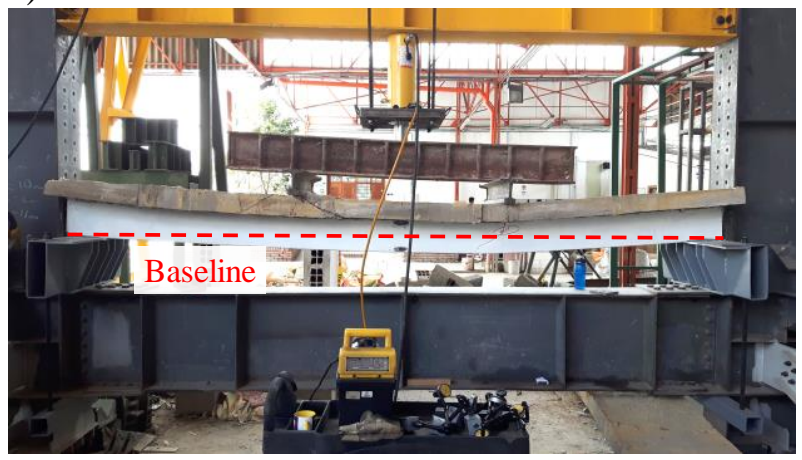

b)

Source: Authors.

The $2 \mathrm{~m}$-long beams showed elastic and maximum deflections between $250 \%$ and $400 \%$ in $21 \mathrm{MPa}$ and $28 \mathrm{MPa}$ strength concrete, respectively. Regarding $4 \mathrm{~m}$ long beams, ratios were around $174 \%$, showing lower inelastic capacity than the previous ones.

Table 5 summarizes the elastic and maximum deflections and loads of the tests.

Table 5. Summary of the Representative Loads and Deflections in Full-Scale Beam Test

\begin{tabular}{|l|l|c|c|c|c|}
\hline $\begin{array}{l}\text { Concrete } \\
\text { strength }\end{array}$ & $\begin{array}{l}\text { Beam } \\
\text { length }\end{array}$ & Parameter & Elastic & Maximum & $\begin{array}{c}\text { Ratio } \\
\text { Max./Elas. }\end{array}$ \\
\hline \multirow{3}{*}{$21 \mathrm{MPa}$} & \multirow{2}{*}{$2 \mathrm{~m}$} & Load $(\mathrm{kN})$ & 206.01 & 251.43 & 1.22 \\
\cline { 2 - 6 } & \multirow{2}{*}{$4 \mathrm{~m}$} & Deflection $(\mathrm{mm})$ & 10.11 & 25.26 & 2.50 \\
\cline { 3 - 6 } & \multirow{2}{*}{$2 \mathrm{~m}$} & Loflection $(\mathrm{kN})$ & 127.53 & 164.32 & 1.29 \\
\hline \multirow{3}{*}{$28 \mathrm{MPa}$} & & Load $(\mathrm{kN})$ & 166.32 & 56.33 & 1.74 \\
\cline { 2 - 6 } & \multirow{2}{*}{$4 \mathrm{~m}$} & Deflection $(\mathrm{mm})$ & 7.93 & 268.40 & 1.61 \\
\cline { 3 - 6 } & & Deflection $(\mathrm{kN})$ & 117.72 & 150.49 & 4.04 \\
\hline
\end{tabular}

Source: Authors. 
As shown in Figure 11, test instrumentation allowed to record vertical and longitudinal displacements. Then, deflection curves are presented in Figure 18. Lengths of the beams were normalized as a percentage of the total length. The figure includes displacements at midspan and thirds in length. Additionally, baselines of the service limit state were included, in order to compare the final condition of specimens. It can be observed that the behavior of the composite sections remains in the elastic range under the service conditions, regardless of the compressive strength of concrete, which becomes a relevant factor under subsequent load levels (Figures 18 and 19).

Figure 18. Deflection Curves for Full-Scale Beam Test

\section{DEFLECTION CURVES}

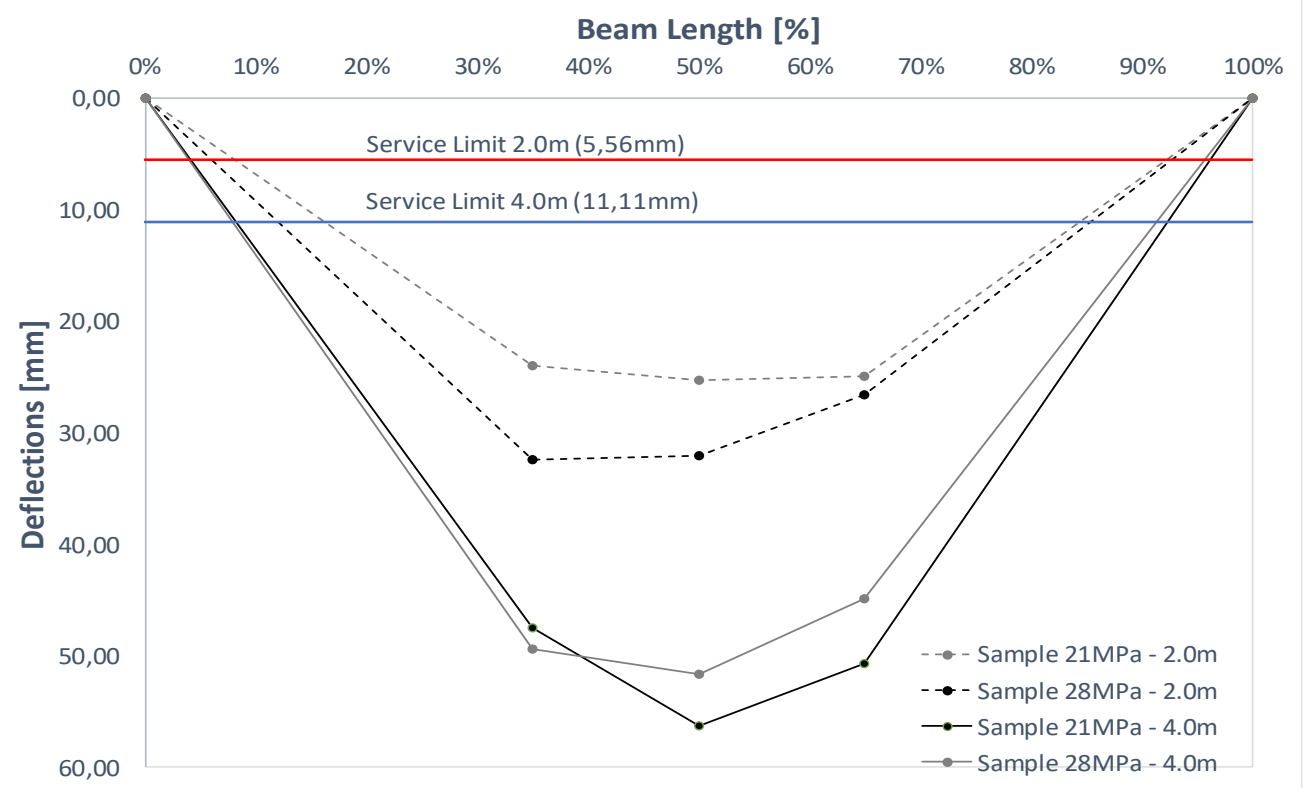

Source: Authors.

Based on the behavior of the curves (Figure 18), the maximum specimen deformations exceed around 5 times the limits for service condition in both lengths, as presented in Table 6.

Table 6. Deflection Results for Full-Scale Beam Test

\begin{tabular}{|l|c|c|c|}
\hline No. & $\begin{array}{c}\text { Maximum deflection in } \\
\text { experimental test } \\
(\Delta \max .)\end{array}$ & $\begin{array}{c}\text { Allowable deflection under } \\
\text { service condition L/360 } \\
(\Delta \text { allow. })\end{array}$ & Ratio \\
& $(\mathrm{mm})$ & $(\mathrm{mm})$ & \multirow{2}{*}{$\Delta \mathrm{max} / \Delta \mathrm{adm}$} \\
\hline $21-2$ & 25.26 & 5.56 & 4.54 \\
\hline $21-4$ & 56.33 & 11.11 & 5.07 \\
\hline $28-2$ & 32.04 & 5.56 & 5.76 \\
\hline $28-4$ & 51.69 & 11.11 & 4.65 \\
\hline
\end{tabular}

Source: Authors. 
Figure 19 shows Load-Deflection curves in 2 m-long beams and $4 \mathrm{~m}$-long beams. Nominal elastic and plastic limits are included as the expected range of structural behavior, as well as service limits.

Figure 19. Load-Deflection Curves for Experimental Full-Scale Beam Test LOAD Vs. DEFLECTION MID SPAN

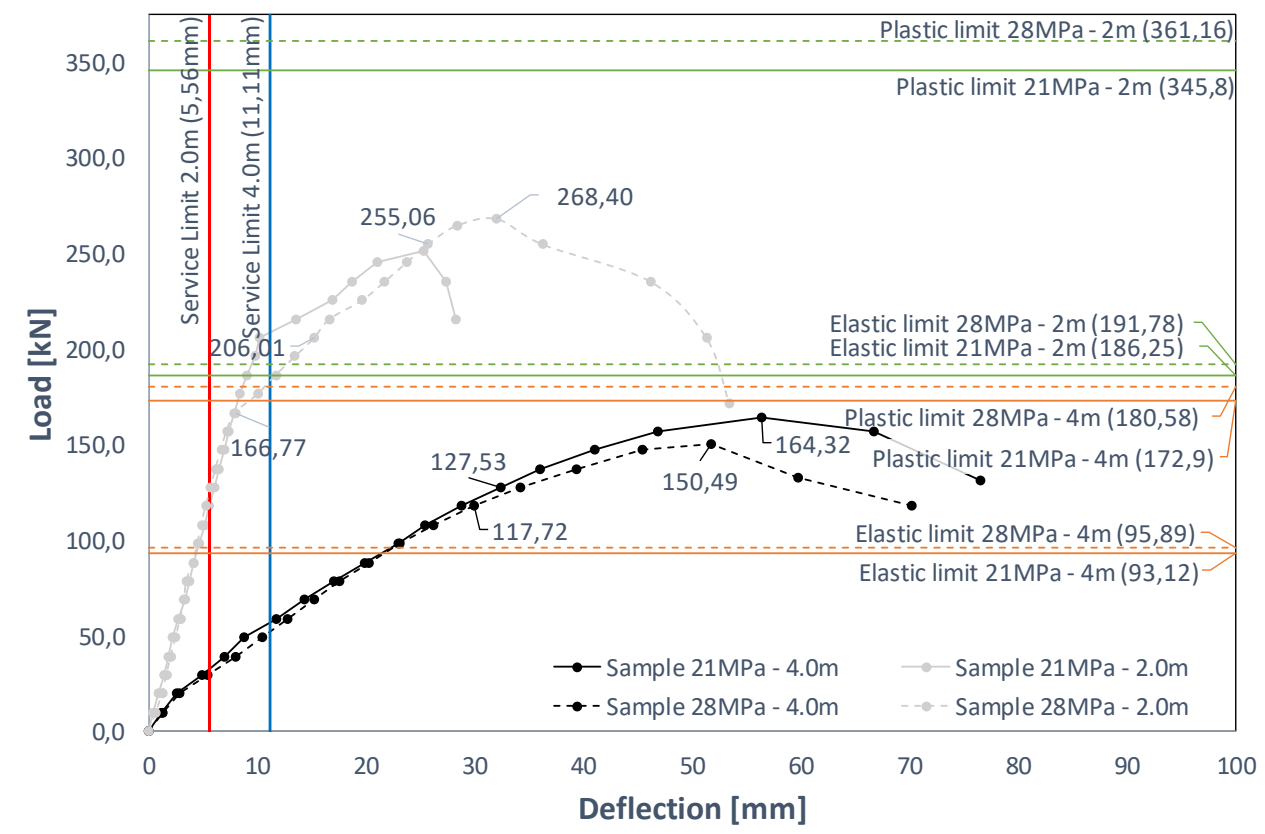

Source: Authors.

As shown in Figure 19, on the one hand, 4 m-long beams showed a behavior close to the nominal plastic load capacity of the composite section, $95 \%$ in $21 \mathrm{MPa}$ concrete (black continuous line) and $83 \%$ in $28 \mathrm{MPa}$ concrete (black dotted line). Furthermore, the elastic loads, included in Table 5, exceeded the nominal elastic limits, 1.37 times and 1.22 times in $21 \mathrm{MPa}$ and $28 \mathrm{MPa}$, respectively. Deflections at the maximum loads evidenced 1.09 times greater values in $21 \mathrm{MPa}$ concrete than in $28 \mathrm{MPa}$ concrete.

On the other hand, the maximum loads of the $2 \mathrm{~m}$-long beams present intermediate values between nominal plastic and elastic conditions (grey lines), reaching around $74 \%$ of the nominal plastic load. The elastic loads are around $\pm 10 \%$ of the predicted nominal values. The deflection at the maximum loads was 1.25 greater in $28 \mathrm{MPa}$ specimens than in the ones of $21 \mathrm{MPa}$.

The widest differences in elastic deflections were around $25.0 \mathrm{~mm}$ between specimens of the same length, found in 2 m-length beams (grey lines). In the longest specimens, the difference is lower than $3.0 \mathrm{~mm}$.

Once elastic behavior is exceeded, cracking and fracture are induced in the concrete slab, mainly beneath the load application point, as shown in Figure 20. Due to asymmetry in the final condition of deflections (Figure 18), the cracks in the concrete slab presented different patterns. 
Figure 20. Concrete Slab Fracture in Full-Scale Beam Test a) General View

b) Detailed View

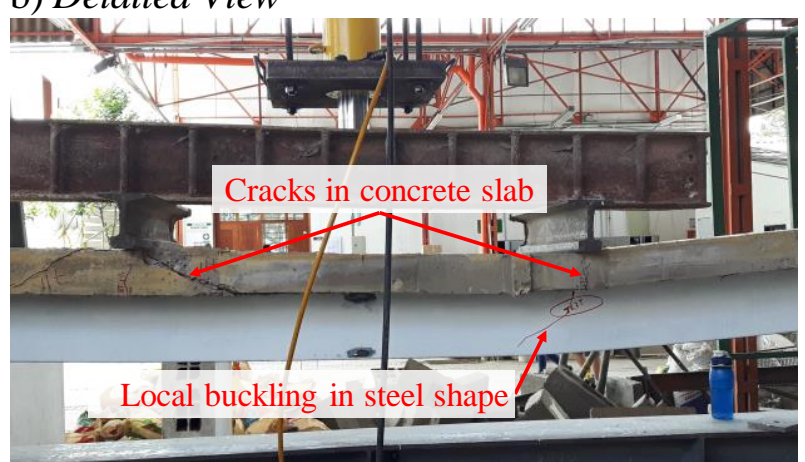

a)

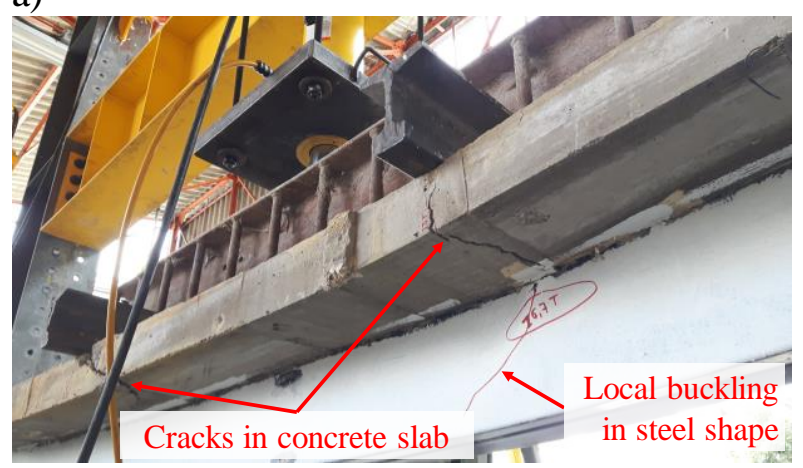

b)

Source: Authors.

Similarly, in the steel section, local buckling is generated due to an increase in the load. Displacements of the steel plates outside the load plane were produced, as shown in Figure 21.

Figure 21. Local Buckling in Steel Shape in Full-Scale Beam Test a) General View b) Lateral Plate Detailing

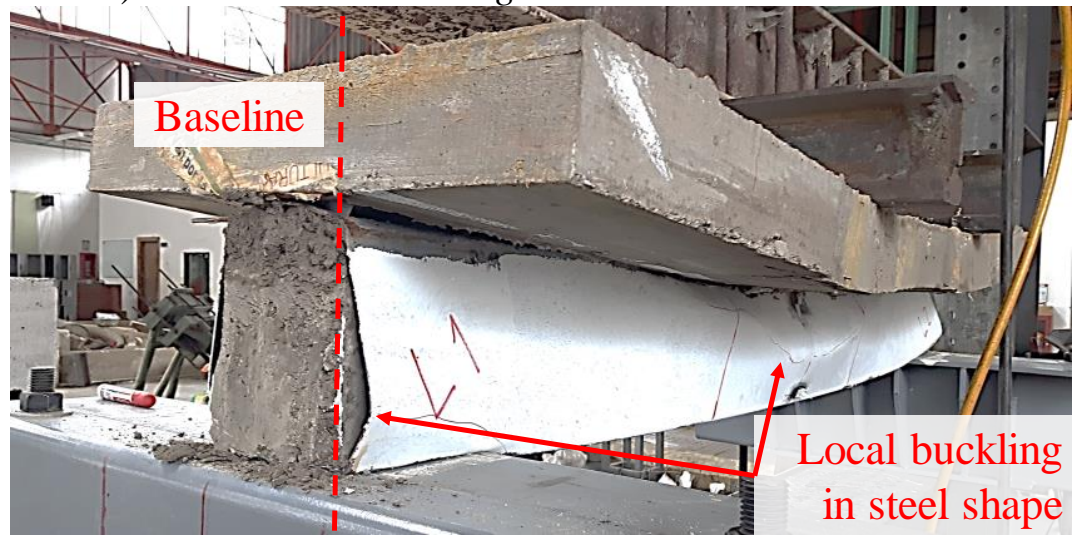

a) 


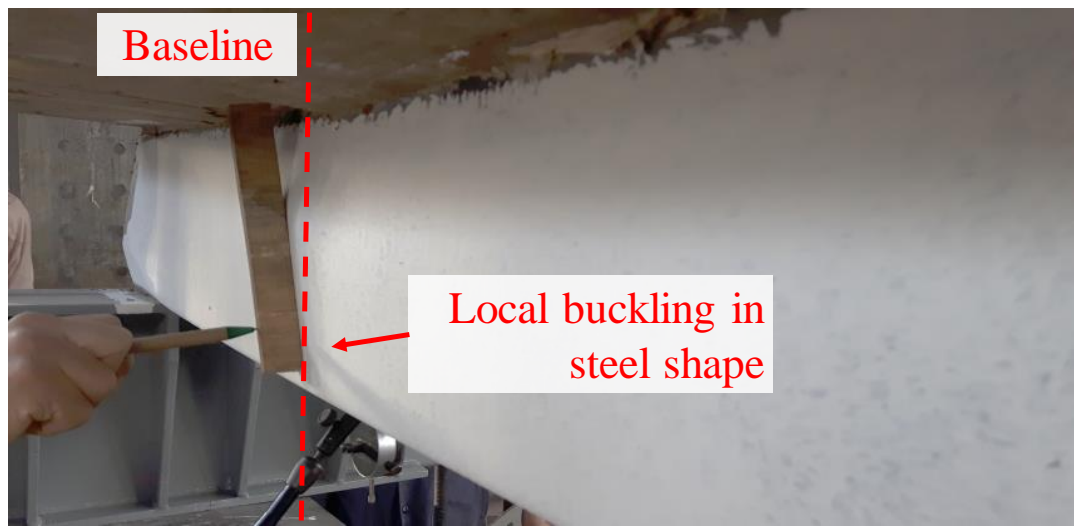

b)

Source: Authors.

Additionally, strains were recorded through strain gauges installed on vertical steel plates, located at $20 \mathrm{~mm}$ from each upper and lower border (Figure 11). The initial and final results are included in Figure 22, where the intersection with the Y-axis indicates the location of the neutral axis (marked as horizontal dotted lines), equivalent to zero strain. According to results, downward displacement of the neutral axis is perceived, through increases in load, predominantly in $4 \mathrm{~m}$-long beams. Therefore, the performance of the composite system was progressively reduced, transferring work only to steel capacity, obtaining independent action of materials at the final state.

Figure 22. Strain State in Composite Section Beams

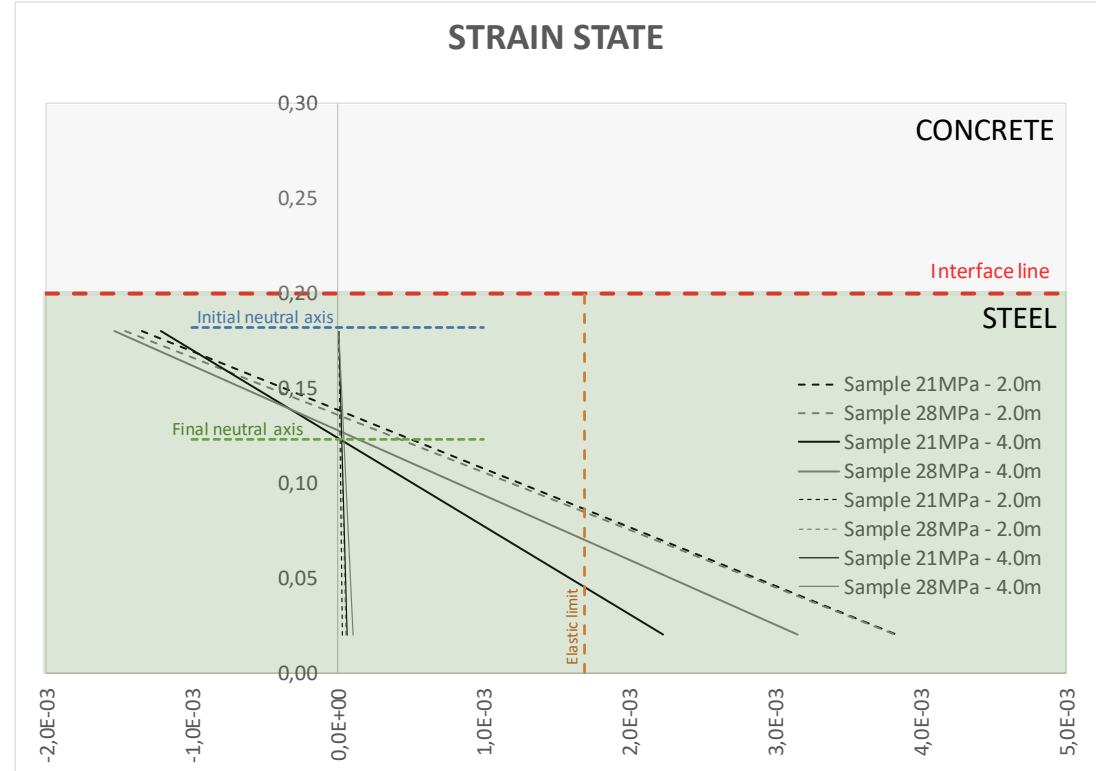

Source: Authors.

Once the experimental tests were completed, the concrete slab was removed, to know the final state of the shear connectors fastening system after working as elements of stress transference between materials (Figures 23 and 24). 
Figure 23. Final State of Self-Drilling Screws Fastening System

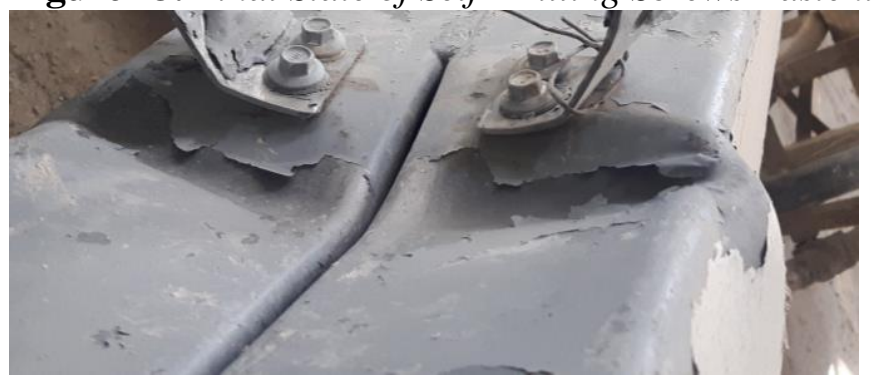

Source: Authors.

Figure 24. CFS Shapes Separation in the Assembled Box Section

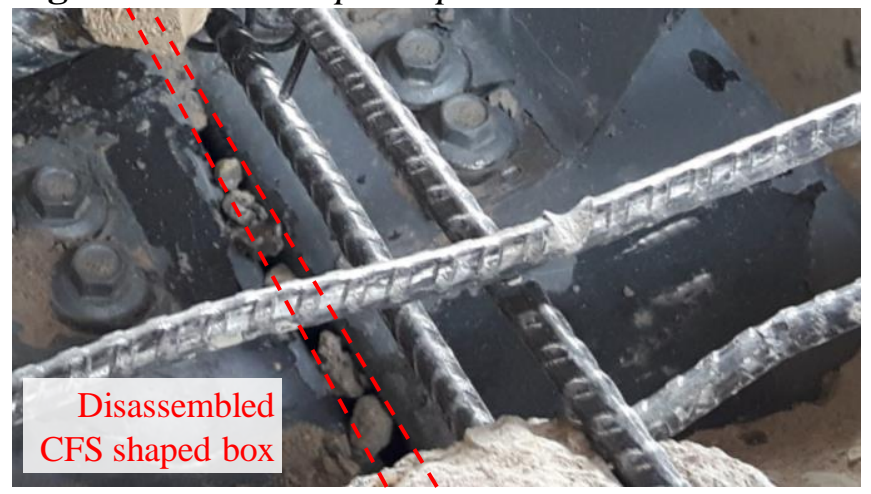

Source: Authors.

According to Figures 23 and 24, the self-drilling screw system kept integrity by itself. Shear connectors remained attached to the CFS shape, without evidence of damages by tearing in the area of the perforations, nor by shearing in screws. System deformation was governed mainly by local buckling in the steel section and, to a lesser extent, by cracking in the slab concrete. Thus, the CFS shape becomes the restrictive element in the capacity of the composite systems.

Likewise, the intermittently welded CFS shape box was disassembled, due to high displacements and deformations of the cross-section (Figure 24).

Based on the results evidenced in this study, it can be concluded that the selfdrilling screws fastening mechanism of shear connectors provide a stable joint. It is capable to develop a high capacity of stress transfer in the interface between materials, allowing large deflections in the composite section, without local damages or detachment of the system.

\section{Conclusions}

In this research, the self-drilling screws were characterized as an alternative fastening mechanism. Its mechanical capacity during the transfer of stresses to composite systems was validated through experimental tests. Results prove them to be an alternative to welding, mainly in the CFS shapes.

The mechanism allowed composite sections to develop an inelastic capacity before presenting damages caused by local buckling in the CFS sections, without 
becoming the weakest element of the system. In addition, recorded deflections exceeded the service limits widely without evidence of screws detachment and showing high ductility.

The ultimate capacities in the full-scale beam test were within the nominal range (elastic-plastic), approaching the plastic behavior in $95 \%$ and $74 \%$ in $4 \mathrm{~m}$ long beams and $2 \mathrm{~m}$-long beams, respectively. This allows establishing predictions of analytical capacity in both cases, which exceeded elastic capacity as suggested in design codes such as AISC 360 and Eurocode4, which are the main international references.

According to the experimental results of screw shear tests, the failure modes presented an adequate correlation compared to the design formulation loads, mainly in the failure of $2.0 \mathrm{~mm}$ thickness plates. In thinner plates, the nominal capacity load exceeded the experimental data.

Plates of more than $2.0 \mathrm{~mm}$ thickness presented failure mechanism caused by shear screws. In contrast, plates with lower thickness failed due to bearing plates or tension on the net section in the thinnest plate but showing greater ductility.

The CFS samples are particularly susceptible to be affected in their mechanical properties during the experimental tests, due to the limited thickness. Therefore, procedures must be highly controlled to avoid alterations in the data record.

The self-drilling system has a better structural performance as a fastening mechanism than the powder-actuated fastening system, due to its high mechanical strength and ease to be implemented in construction.

\section{Acknowledgements}

The authors thank the management and financial support of the Research and Extension Office of the Faculty of Engineering of Universidad Nacional de Colombia, for the project "Comportamiento de secciones compuestas aceroconcreto con conectores de cortante tipo tornillo a partir de experimentación y simulación numérica" in the framework of the National Call for Strengthening, Creation and Innovation of the University 2016-2018.

\section{References}

Alhajri T, Tahir M, Azimi M, Mirza J, Lawan M, Alenezi K et al. (2016) Behavior of precast u-shaped composite beam integrating cold-formed steel with ferro-cement slab. Thin-Walled Structures 102(May): 18-29.

American Institute of Steel Construction - AISC (2016) Specification for structural steel buildings (AISC 360-16). USA.

American Iron and Steel Institute - AISI (2016) North American specification for the design of cold-formed steel structural members (S-100). USA.

Associacao Brasileira de Normas Tecnicas - ABNT (2008) Norma brasileira ABNT NBR 8800. (Brazilian standard ABNT NBR 8800) Brazil. 
Australian/New Zeland Standards - AS/NZ (2005) Cold formed steel structures (AS/NZ 4600:2005). Australia.

Canadian Standards Association - CSA (2007) North American specification for the design of cold formed steel structural members (S136-07). Canada.

Derlatka A, Lacki P, Nawrot J, Winoviecka J (2019) Numerical and experimental test of steel concrete composite beam with the connector made of top-hat profile. Composite Structures 211(Mar): 244-253.

Erazo L, Molina M (2017) Comportamiento de conectores de cortante tipo tornillo en secciones compuestas con lámina colaborante. (Behavior of screw type shear connectors in composite sections with collaborating sheet). Master Thesis. Colombia: Civil Engineering - E-structures, Universidad Nacional de Colombia.

European Committee Standardization - ECS (2004) Eurocode 4: design of composite steel and concrete structures.

Fontana M, Bärtschi R (2002) New types of shear connectors with powder-actuated fasteners. Zurich: ETH Zürich Research Collection. Institute of Structural Engineering - Swiss Federal Institute of Technology.

Hanaor A (2000) Tests of composite beams with cold-formed sections. Journal of Constructional Steel Research 54(2): 245-264.

Hancock G (2003) Cold-formed steel structures. Journal of Constructional Steel Research 59(4): 473-487.

Hossain A (2005) Designing thin-walled composite-filled beams. Proceedings of the Institution of Civil Engineers. Structures \& Buildings 158(4): 267-278.

Irvwan J, Hanizah A (2009) Test of shear transfer enhancement in symmetric cold-formed steel concrete composite beams. Journal of Constructional Steel Research 65(12): 2087-2098.

Japan Society of Civil Engineers - JSCE (2007) Standard specifications for steel and composite structures. Japan.

Kyvelou P, Gardner L, Nethercot D (2017) Design of composite cold-formed steel flooring systems. Structures 12(Nov): 242-252.

Kyvelou P, Gardner L, Nethercot D (2018) Finite element modelling of composite coldformed steel flooring systems. Engineering Structures 158(Mar): 28-42.

Lakkavalli B, Liu Y (2006) Experimental study of composite cold-formed steel c-section floor joist. Journal of Constructional Steel Research 62(10): 995-1006.

Lawan M, Tahir M, Ngian S, Sulaiman A (2015) Structural performance of cold-formed steel section in composite structures: A review. Jurnal Teknologi 74(4): 65-175.

Lawan M, Tahir M (2015) Strength capacity of bolted shear connectors with cold-formed steel section integrated as composite beam in self-compacting concrete. Jurnal Teknologi 77(16): 105-112.

Lawan M, Tahir M, Osman H (2015) Composite construction of cold-formed steel (CFS) section with high strength bolted shear connector. Jurnal Teknologi 77(16): 171-179.

Lawson R, Popo-Ola S, Varley D (2001) Innovative development of light steel composites in buildings. In International Union of Laboratories and Experts in Construction Materials and Structures (RILEM). International Symposium on Connections between Steel and Concrete.

Merryfield G, El-Ragaby A, Ghrib F (2016) New shear connector for open web steel joist with metal deck and concrete slab floor system. Construction and Building Materials 125(Oct): 1-11.

Queiroz G, Rodrigues F, Pereira S, Pfeil M, Oliveira C, Da Mata L (2010) Behavior of steel concrete beams with flexible shear connectors. In International Colloquium on Stability and Ductility of Steel Structures 2006. Volume 1: 863-870. 
Tahir M, Saggaff A, Azimi M, Lawan M (2016a) Impact of bolted shear connector spacing in composite beam incorporating cold formed steel of channel lipped section. IIOAB Journal 7: 441-445.

Tahir M, Saggaff A, Azimi M, Lawan M (2016b) Influence of bolted shear connector size in push-out test for composite construction with cold formed steel section. IIOAB Journal 7: 521-526.

Valencia G (2010) Diseño básico de estructuras de acero de acuerdo con NSR-10. (Basic design of steel structures in accordance with NSR-10). $1^{\text {st }}$ Edition. Bogotá, Colombia: Editorial Escuela Colombiana de Ingeniería.

Yu WW, LaBooube R (2010) Cold formed steel design. $4^{\text {th }}$ Edition. New Jersey, USA: John Wiley \& Sons Inc. 